\title{
Bioremediation of Uranium- and Nitrate-Contaminated Groundwater after the In Situ Leach Mining of Uranium
}

\author{
Rehemanjiang Wufuer ${ }^{1}$, Jia Duo ${ }^{1}$, Wenfeng $\mathrm{Li}^{1, *}$, Jinglong Fan ${ }^{2}$ and Xiangliang Pan ${ }^{3, *}$ \\ 1 Xinjiang Key Laboratory of Environmental Pollution and Bioremediation, Xinjiang Institute of Ecology \\ and Geography, Chinese Academy of Sciences, Urumqi 830011, China; reheman319@ms.xjb.ac.cn (R.W.); \\ duojia2017@ms.xjb.ac.cn (J.D.) \\ 2 Desert Engineering Survey and Design Institute, Xinjiang Institute of Ecology and Geography, \\ Chinese Academy of Sciences, Urumqi 830011, China; fanjl@ms.xjb.ac.cn \\ 3 Key Laboratory of Microbial Technology for Industrial Pollution Control of Zhejiang Province, \\ College of Environment, Zhejiang University of Technology, Hangzhou 310014, China \\ * Correspondence: liwf86@ms.xjb.ac.cn (W.L.); panxl@ms.xjb.ac.cn (X.P.)
}

Citation: Wufuer, R.; Duo, J.; Li, W.; Fan, J.; Pan, X. Bioremediation of

Uranium- and Nitrate-Contaminated Groundwater after the In Situ Leach Mining of Uranium. Water 2021, 13, 3188. https://doi.org/10.3390/ w13223188

Academic Editor:

Fabienne Battaglia-Brunet

Received: 22 October 2021

Accepted: 8 November 2021

Published: 11 November 2021

Publisher's Note: MDPI stays neutral with regard to jurisdictional claims in published maps and institutional affiliations.

Copyright: () 2021 by the authors. Licensee MDPI, Basel, Switzerland. This article is an open access article distributed under the terms and conditions of the Creative Commons Attribution (CC BY) license (https:// creativecommons.org/licenses/by/ $4.0 /)$.

\begin{abstract}
Uranium and nitrate are common groundwater pollutants near in situ leach uranium mines. However, we still lack techniques that can simultaneously immobilize uranium and reduce nitrate using a single bacterial species. In this study, the potential of simultaneous uranium immobilization and nitrate reduction by a single AFODN (anaerobic Fe(II) oxidizing denitrifier), Clostridium sp. PXL2, was investigated. Clostridium sp. PXL2 showed tolerance to U(VI) concentrations varying from $4.2 \mu \mathrm{M}$ to $42 \mu \mathrm{M}$. The $\mathrm{U}(\mathrm{VI})$ immobilization and nitrate reduction rates in groundwater samples inoculated with this bacterium reached up to $75.1 \%$ and $55.7 \%$, respectively, under neutral conditions. Exposure to oxidation conditions led to further $\mathrm{U}(\mathrm{VI})$ removal but did not show any noticeable effect on nitrate reduction. The U(VI) immobilization rate reached up to $85 \%$ with an increased $\mathrm{Fe}(\mathrm{II})$ initial concentration, but this inhibited nitrate reduction. SEM (scanning electron microscopy) coupled with EDS (energy dispersive spectroscopy) showed that the U(VI) immobilization was mainly due to sorption to amorphous ferric oxides. U(VI) and nitrate bioremediation by AFODNs, including Clostridium sp. PXL2, may provide a promising method for the treatment of uranium- and nitrate-contaminated groundwater after the in situ leach mining of uranium.
\end{abstract}

Keywords: Clostridium sp. PXL2; immobilization; reduction

\section{Introduction}

Uranium pollution has become a serious environmental concern because of extensive uranium mining, leaching, and the poor processing of by-products generated during mining activities [1]. ISL (in situ uranium leaching) techniques were developed in the USA and have also been broadly used in Eastern Europe, including the former Soviet Union, and some parts of Asia. However, the leaching solutions from ISL mines contain high levels of uranium and nitrate, which contaminate nearby aquifers and cause serious pollution to the groundwater. The uranium and nitrate concentrations in leaching solutions at some typical ISL mines are given in Table 1. The uranium concentration in the groundwater in uranium mining and milling sites can range from $1 \mathrm{mM}$ to $210 \mathrm{mM}$ [2,3]. Long-term exposure to uranium-polluted drinking water can cause serious health problems, including renal function damage or kidney failure $[4,5]$. The permissible value for uranium in drinking water is set as $2.0 \mathrm{mg} \mathrm{L}^{-1}$ by the World Health Organization [6] and is $30 \mu \mathrm{g} \mathrm{L}^{-1}$ in the USA [7]. Nitrate is another common pollutant produced by uranium leaching and processing due to the use of nitric acid or ammonia $[8,9]$. Groundwater nitrate levels have been observed to reach up to $130 \mathrm{mM}$ in Oak Ridge, TN [8], and $19.7 \mathrm{mM}$ in mill tailing sites near Tuba City, AZ (USA) [10]. The main health problem associated with nitrate is blue baby syndrome, which is caused by the reaction of nitrate with hemoglobin [11]. The guideline value for nitrate in groundwater is set as $10 \mathrm{mg} \mathrm{L}^{-1}$ in many countries [12]. 
Table 1. Leaching solution quality in some in situ leaching mines $\left(\mathrm{mg} \mathrm{L}^{-1}\right)$.

\begin{tabular}{cccc}
\hline & Czech Rep. & Uzbekistan & Yining, China \\
\hline nitrate & $200-1400$ & 750 & - \\
$\mathrm{U}(\mathrm{VI})$ & $20-500$ & 86 & 75 \\
\hline Data derived from [13,14]. & & &
\end{tabular}

In recent decades, a number of biotechnologies, including biomineralization [15-17], bioreduction [18-21], biosorption [22-25], and bioaccumulation [26], have been proposed in order to immobilize uranium in contaminated groundwater. Among the uranium bioremediation techniques available, uranium bioreduction has been studied extensively, where $\mathrm{U}(\mathrm{VI})$ is reduced to $\mathrm{U}(\mathrm{IV})$ by a variety of bacteria. In situ demonstrations of uranium bioreduction have been conducted successfully at the US DOE Rifle site, Colorado [27], and at the US DOE Oak Ridge site, Tennessee [28,29]. However, the stability of reduced U(IV) depends on protecting it from re-oxidation by nitrate [30,31] and $\mathrm{O}_{2}$ [28]. Even certain intermediates of denitrification products such as nitrite and nitric oxide have been shown to cause the re-oxidation of U(IV) [32]. Therefore, the coexistence of nitrate with uranium poses a challenge when using this technique as a viable uranium bioremediation strategy for polluted groundwater [31,32]. Generally, uranium biomineralization has only been studied at the laboratory scale due to the high cost of organic phosphates and other toxic effects on cell metabolism $[9,33]$.

There is, therefore, an urgent need to find cost-effective biological techniques that can remediate groundwater contaminated with uranium and nitrate. Although uranium and nitrate are frequently detected together in groundwater near uranium mines and milling sites, especially at in situ leaching uranium sites, currently we still lack biotechnologies that can simultaneously remove uranium and nitrate using a single species of bacteria. Bacterial species known as AFODNs have been reported to oxidize Fe(II) to Fe(III) under anoxic conditions $[34,35]$. AFODNs can simultaneously reduce nitrate to denitrification intermediates such as nitric oxide and nitrogen. They also produce ferric oxides that have a great adsorption capacity for $\mathrm{U}(\mathrm{VI})[36,37]$. These anaerobes may therefore provide a novel solution to concurrently remediate uranium and nitrate contaminated groundwater arising from in situ uranium mining, milling, and leaching sites.

The purpose of this study was to simulate polluted groundwater after the in situ leach mining of uranium and to investigate the potential of the AFODN bacterium, Clostridium sp. PXL2, for the simultaneous removal of uranium and nitrate. The effects of environmental factors such as $\mathrm{pH}$, oxidation, and $\mathrm{Fe}(\mathrm{II})$ on uranium immobilization and nitrate reduction by this anaerobe were assessed. SEM-EDS analysis was applied to characterize the adsorption of uranium by the biogenic iron oxides.

\section{Materials and Methods}

\subsection{Sample Collection and Processing}

Groundwater samples were collected from a uranium rich coal mining site in Xinjiang, China. The groundwater was pumped up by an electric well water pump from a depth of about $150 \mathrm{~m}$ and collected in $100 \mathrm{~L}$ plastic containers, which were completely filled and capped tightly in order to avoid further oxidation. Some basic physical and chemical parameters of the groundwater are listed in Table 2.

Table 2. Physical and chemical parameters of groundwater sample.

\begin{tabular}{|c|c|c|c|c|c|c|c|c|c|c|c|}
\hline $\mathrm{pH}$ & U(VI) & Conductivity & $\mathrm{Cl}^{-}$ & $\mathrm{SO}_{4}{ }^{2-}$ & $\mathrm{Ca}^{2+}$ & $\mathbf{K}^{+}$ & $\mathrm{Mg}^{2+}$ & $\mathrm{Na}^{+}$ & $\mathrm{CO}_{3}{ }^{2-}$ & $\mathrm{HCO}_{3}^{-}$ & Nitrate \\
\hline & $\mu g \mathrm{~L}^{-1}$ & us $\mathrm{cm}^{-1}$ & $\mathrm{mg} \mathrm{L}^{-1}$ & $\mathrm{mg} \mathrm{L}^{-1}$ & $\mathrm{mg} \mathrm{L}^{-1}$ & $\mathrm{mg} \mathrm{L}^{-1}$ & $\mathrm{mg} \mathrm{L}^{-1}$ & $\mathrm{mg} \mathrm{L}^{-1}$ & $\mathrm{mg} \mathrm{L}^{-1}$ & $\mathrm{mg} \mathrm{L}^{-1}$ & $\mathrm{mg} \mathrm{L}^{-1}$ \\
\hline 7.74 & 8.71 & 1238 & 113.1 & 357.9 & 175.6 & 3.4 & 36.6 & 116.0 & 0 & 55.9 & 49.5 \\
\hline
\end{tabular}

The $\mathrm{pH}$ was measured using a $\mathrm{pH}$ meter (Mettler SevenEasy); conductivity was measured by a conductivity detector (DDS-307); $\mathrm{Cl}^{-}$ and $\mathrm{SO}_{4}{ }^{2+}$ were measured by ion chromatography (ICS-5000 Dionex, Waltham, MA, USA); $\mathrm{Ca}^{2+}, \mathrm{K}^{+}, \mathrm{Mg}^{2+}$, and Na ${ }^{+}$were measured by ICP-OES (735, Agilent, Santa Clara, CA, USA); $\mathrm{HCO}_{3}{ }^{-}$and $\mathrm{CO}_{3}{ }^{2-}$ were measured by an automatic potentiometric titrator (G20, Mettler); $\mathrm{U}(\mathrm{VI})$ concentration was measured by ICP-MS (8800, Agilent, USA); nitrate was measured by the photometric method of Slanina et al. [38]. 


\subsection{Culture of Clostridium sp. PXL2}

The anaerobic bacterium was originally isolated from activated sludge collected from the sewage management station of Miquan in Urumqi, China, and identified as Clostridium sp. PXL2 [12]. The bacterium was incubated at $30{ }^{\circ} \mathrm{C}$ in a medium of the following composition ( $\mathrm{L}^{-1}$ deionized water): $0.28 \mathrm{~g} \mathrm{~L}^{-1} \mathrm{NH}_{4} \mathrm{CI}, 0.25 \mathrm{~g} \mathrm{~L}^{-1} \mathrm{KH}_{2} \mathrm{PO}_{4}$, $0.1 \mathrm{~g} \mathrm{~L}^{-1} \mathrm{MgSO}_{4}, 0.1 \mathrm{~g} \mathrm{~L}^{-1}$ yeast extract, $0.5 \mathrm{~g} \mathrm{~L}^{-1} \mathrm{KNO}_{3}, 0.5 \mathrm{~g} \mathrm{~L}^{-1} \mathrm{FeCI}_{2} \cdot 4 \mathrm{H}_{2} \mathrm{O}$. The growing culture was used for further experiments after 1 week of incubation at $30^{\circ} \mathrm{C}$. The initial optical density $\left(\mathrm{OD}_{600}\right)$ of the experimental bacterium was adjusted to 0.2 .

\subsection{Groundwater Treatments}

Groundwater was amended with $0.3 \mathrm{~g} \mathrm{~L}^{-1}$ of yeast extract and then sterilized using $0.22 \mu \mathrm{m}$ hydrophilic polyestersulfone membrane filters. The sterile groundwater was placed in an anaerobic chamber overnight in order to remove dissolved oxygen. The $\mathrm{pH}$ was adjusted with $0.1 \mathrm{M}$ sodium hydroxide solution or $0.1 \mathrm{M}$ hydrochloric acid. The groundwater was supplemented with filter-sterilized $1.0 \mathrm{~g} \mathrm{~L}^{-1} \mathrm{U}(\mathrm{VI})$ stock solution and $130 \mathrm{~g} \mathrm{~L}^{-1}$ sodium nitrate solution to provide initial concentrations of $1.5 \mathrm{mg} \mathrm{L}^{-1} \mathrm{U}(\mathrm{VI})$ and $1050 \mathrm{mg} \mathrm{L}^{-1}$ nitrate, respectively. Various Fe(II) concentrations were obtained using filtersterilized $35.2 \mathrm{~g} \mathrm{~L}^{-1} \mathrm{Fe}(\mathrm{II})\left(\mathrm{FeCI}_{2} \cdot 4 \mathrm{H}_{2} \mathrm{O}\right)$ stock solution. All manipulations and experiments were conducted in $250 \mathrm{~mL}$ serum bottles in an anaerobic workstation at $30{ }^{\circ} \mathrm{C}$. A $2 \%(v / v)$ Clostridium PXL2 culture was inoculated into the test samples after supplementing with the other chemicals. The Fe(II), $\mathrm{U}(\mathrm{VI})$, nitrate, and nitrite concentrations were measured every $24 \mathrm{~h}$. All experiments were conducted in triplicate.

\subsection{Measurement of Growth}

Clostridium sp. PXL2 was inoculated in the above-mentioned selective media in $100 \mathrm{~mL}$ serum bottles containing various $\mathrm{U}(\mathrm{VI})$ concentrations $(0,4.2,10.5,21.0,42.0 \mu \mathrm{M})$ and cultivated at $30{ }^{\circ} \mathrm{C}$ in the DG250 anaerobic workstation. Samples without U(VI) were used as controls. Using a UV2800 spectrophotometer (Unico, Shanghai, China), we measured the bacterial growth at $600 \mathrm{~nm}\left(\mathrm{OD}_{600}\right)$ at exposure to $\mathrm{U}(\mathrm{VI})$ for $12,24,36,48,60$, 72 , and $84 \mathrm{~h}$.

\subsection{Analytical Methods}

The concentrations of $\mathrm{Fe}(\mathrm{II}), \mathrm{U}(\mathrm{VI})$, nitrate, and nitrite were measured by spectrophotometric methods using a UV2800 spectrophotometer. The Fe(II) concentration was determined by a modified phenanthroline method at $510 \mathrm{~nm}$ [39]. Instead of using a $25 \% \mathrm{HCI}$ solution, $40 \mathrm{mM}$ of sulfamic acid was used, as this reacts quickly with nitrite and prevents $\mathrm{Fe}(\mathrm{II})$ oxidation by the nitrite at acidic $\mathrm{pH}$ values [40]. U(VI) concentration was monitored using an optimized photometric Arsenazo-III method at $651 \mathrm{~nm}$ [41]. Briefly, several milliliters of prefiltered $(0.22 \mu \mathrm{m})$ groundwater samples were heated slowly to near dryness followed by the addition of $0.007 \%$ Arsenazo-III solution. A total of $0.007 \%$ Arsenazo-III solution was prepared by dissolving Arsenazo-III in $3 \mathrm{~mol} \mathrm{~L}^{-1}$ of $\mathrm{HClO}_{4}(w / v)$. The final volume was made up to $5.0 \mathrm{~mL}$ in a volumetric flask by using the same Arsenazo-III solution. The absorbance was measured at $651 \mathrm{~nm}$ against the reagent blank after thorough mixing. The nitrate concentration was measured at 220 and $275 \mathrm{~nm}$. Certain amounts of prefiltered groundwater samples were added to $50 \mathrm{~mL}$ colorimetric tubes and diluted to $50 \mathrm{~mL}$ with distilled water followed by the addition of $1 \mathrm{~mL}$ of $1 \mathrm{~mol} \mathrm{~L}^{-1}$ hydrochloric acid. An amount of $50 \mathrm{~mL}$ of distilled water plus $1 \mathrm{~mL}$ of hydrochloric acid was used as reference. A quartz cuvette of optical length $10 \mathrm{~mm}$ was used for the measurement [38]. The nitrite concentration was determined to be $540 \mathrm{~nm}$. Certain amounts of prefiltered groundwater samples were added to $50 \mathrm{~mL}$ colorimetric tubes and diluted to $50 \mathrm{~mL}$ with distilled water. A total of $1 \mathrm{~mL}$ of chromogenic agent ( $\mathrm{N}$-(a-naphthyl)-ethylenediamine) was added and thoroughly mixed. Distilled water was used as a reference. The samples were measured after resting for $20 \mathrm{~min}$ [42]. 
Biogenic Fe(II) oxidation sediments and bacterial cells were examined by SEM-EDS. Sediment samples for SEM-EDS analysis were prepared as follows. First, the samples were centrifuged for $5 \mathrm{~min}$ at $8000 \mathrm{rpm}$ and supernatants were abandoned. Pellets were washed with distilled water. This process was repeated 3 times. Afterwards, the washed pellets were frozen at $-80^{\circ} \mathrm{C}$ for $4 \mathrm{~h}$ before drying at $-60{ }^{\circ} \mathrm{C}$ for $48 \mathrm{~h}$. A scanning electron microscope (Zeiss Super 55VP, Oberkochen, Germany) was used for analyzing our samples. Then, we used an energy dispersive X-ray spectrometer (Bruker XFlash 5010, Karlsruhe, Germany) to confirm the elemental composition of the sediments.

\subsection{Chemicals}

$\mathrm{U}(\mathrm{VI})$ was applied in the form of analytical-grade uranyl nitrate hexahydrate $\left[\mathrm{UO}_{2}\left(\mathrm{NO}_{3}\right)_{2} \cdot 6 \mathrm{H}_{2} \mathrm{O}\right]$ (Hubei Chushengwei Chemistry Co., Ltd., Wuhan, China). Initially, a $1.0 \mathrm{~g} \mathrm{~L}^{-1}$ stock $\mathrm{U}(\mathrm{VI})$ solution was prepared in deionized water and stored at $4{ }^{\circ} \mathrm{C}$. Other chemicals included $\mathrm{FeCl}_{2} \cdot 4 \mathrm{H}_{2} \mathrm{O}$ (analytical grade, Beijing Kangpu Huiwei Technology Co., Ltd., Beijing, China) and sodium nitrate (analytical grade, Tianjin Yongsheng Chemical Co., Ltd., Tianjin, China).

\subsection{Statistical Methods}

The Mann-Whitney-Wilcoxon method was applied to determine whether there were significant differences between the subgroups. The t-test statistical method was applied to determine whether there were significant differences between the values of this study and mean (or average) values of other studies.

\section{Results and Discussion}

\subsection{Growth in the Presence of $U(V I)$}

Figure 1 shows the growth of Clostridium sp. PXL2 in the presence of various concentrations of $\mathrm{U}(\mathrm{VI})$. The cell growth in all $\mathrm{U}(\mathrm{VI})$ concentrations showed a trend of steady increase over the $96 \mathrm{~h}$ of incubation. Compared to the control, the cell growth was not significantly affected by $\mathrm{U}(\mathrm{VI})$ exposure to up to $42 \mu \mathrm{M}(p>0.05)$, implying that $\mathrm{U}(\mathrm{VI})$ has no significant toxic effects on this bacterium in an aquatic environment. It is also noticeable from Figure 1 that there was a slight but not significant increase $(p>0.05)$ in the cell growth with the increase in $\mathrm{U}(\mathrm{VI})$ concentrations. This was possibly due to the precipitation of $\mathrm{U}(\mathrm{VI})$ with phosphate ions which were released from NB media during the bacterial cell growth.

\subsection{Influence of $p H$}

Figure 2 shows the changes in $\mathrm{Fe}(\mathrm{II}), \mathrm{U}(\mathrm{VI})$, nitrate, and nitrite concentrations in the control and inoculated ( $\mathrm{pH} 5.5$ and $\mathrm{pH} 7.0)$ cultures over the $96 \mathrm{~h}$ of incubation under anoxic conditions. We observed a decline in the concentrations of $\mathrm{Fe}(\mathrm{II}), \mathrm{U}(\mathrm{VI})$, and nitrate, whereas the nitrite concentration increased (Figure 2a,b). After the $96 \mathrm{~h}$ of incubation, the $\mathrm{Fe}(\mathrm{II})$ concentrations in the inoculated groundwater samples at initial $\mathrm{pH} 5.5$ and $\mathrm{pH} 7.0$ were reduced by $27.2 \%$ and $65.4 \%$, from an initial concentration of $2.35 \mathrm{mM}$ and $1.30 \mathrm{mM}$, respectively (Figure 2a). The lower Fe(II) oxidation rate at $\mathrm{pH} 5.5$ was possibly due to the fact that $\mathrm{Fe}(\mathrm{II})$ is more resistant to oxidation in acidic conditions than at neutrality. Moreover, neutral conditions are more favorable for the growth of Clostridium sp. PXL2 than alkaline or acidic conditions [12]. The U(VI) concentrations in the inoculated $\mathrm{pH} 5.5$ and pH 7.0 samples dropped by $70.0 \%$ and $75.1 \%$, respectively (Figure $2 \mathrm{a}$ ). The estimated molar ratios of immobilized $\mathrm{U}(\mathrm{VI})$ and oxidized $\mathrm{Fe}(\mathrm{II})$ at $\mathrm{pH} 5.5$ and $\mathrm{pH} 7.0$ were 0.0067 and 0.0047 , respectively. The higher effective $\mathrm{U}(\mathrm{VI})$ immobilization at $\mathrm{pH} 5.5$ was due to aqueous $\mathrm{U}(\mathrm{VI})$ being strongly adsorbed to ferric oxides at low $\mathrm{pH}[43,44]$. In higher $\mathrm{pH}$ environments $(\mathrm{pH} \geq 7), \mathrm{UO}_{2}{ }^{2+}$ formed strong aqueous complexes with $\mathrm{CO}_{3}{ }^{2-}$, which greatly enhanced the solubility of $\mathrm{U}(\mathrm{VI})$ in carbonate-containing aquatic environments [45,46]. During the $96 \mathrm{~h}$ of incubation, the nitrate concentrations at $\mathrm{pH} 5.5$ and $\mathrm{pH} 7.0$ rapidly declined with $43.5 \%$ and $55.7 \%$ levels of removal, respectively (Figure $2 \mathrm{~b}$ ). The higher nitrate reduction at 
$\mathrm{pH} 7.0$ was due to the better bacterial growth in a neutral environment [12]. Concurrently, $4.32 \mathrm{mM}$ and $5.72 \mathrm{mM}$ of nitrite were produced at $\mathrm{pH} 5.5$ and $\mathrm{pH} 7.0$ after $96 \mathrm{~h}$, which are lower values than the stoichiometric loss of $7.24 \mathrm{mM}$ and $9.49 \mathrm{mM}$ nitrate. This indicates that nitrite may be further reduced to nitrogen, ammonia, or NO [12]. Comparatively, only $11.9 \%$ of the $\mathrm{Fe}(\mathrm{II})$ and $\mathrm{U}(\mathrm{VI})$ and $8.0 \%$ of the nitrate were removed in the control sample at $\mathrm{pH} 7.0$, while $1.7 \%, 4.7 \%$, and $2.4 \%$ of the $\mathrm{Fe}(\mathrm{II}), \mathrm{U}(\mathrm{VI})$, and nitrate were lost from the control sample at $\mathrm{pH} 5.5$, respectively. This confirmed that the nitrate reduction and $\mathrm{U}(\mathrm{VI})$ immobilization in the groundwater samples were mainly due to the activities of the Clostridium sp. PXL2.

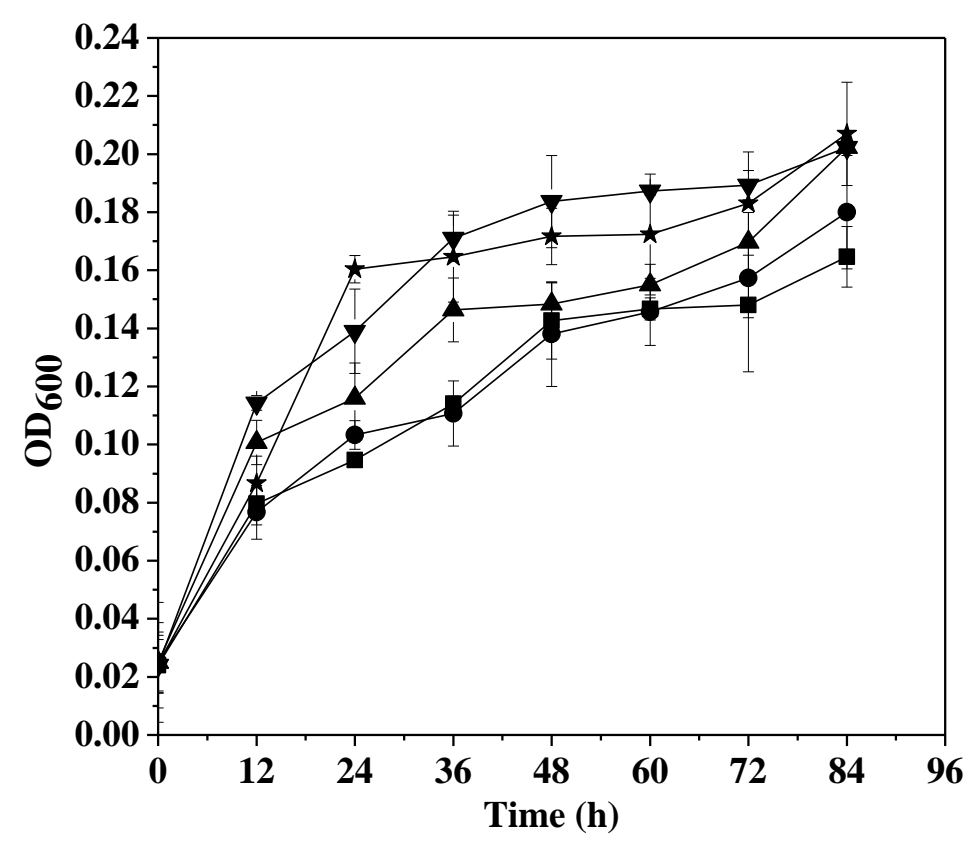

Figure 1. Growth of Clostridium sp. PXL2 at various U(VI) concentrations. $\mathbf{\square}$, control; $\bullet, 4.2 \mu \mathrm{M}$; $\boldsymbol{\Lambda}, 10.5 \mu \mathrm{M} ; \mathbf{\nabla}, 21.0 \mu \mathrm{M} ; \star, 42.0 \mu \mathrm{M}$. Data are presented as means \pm standard deviations (SD) of triplicate measurements.
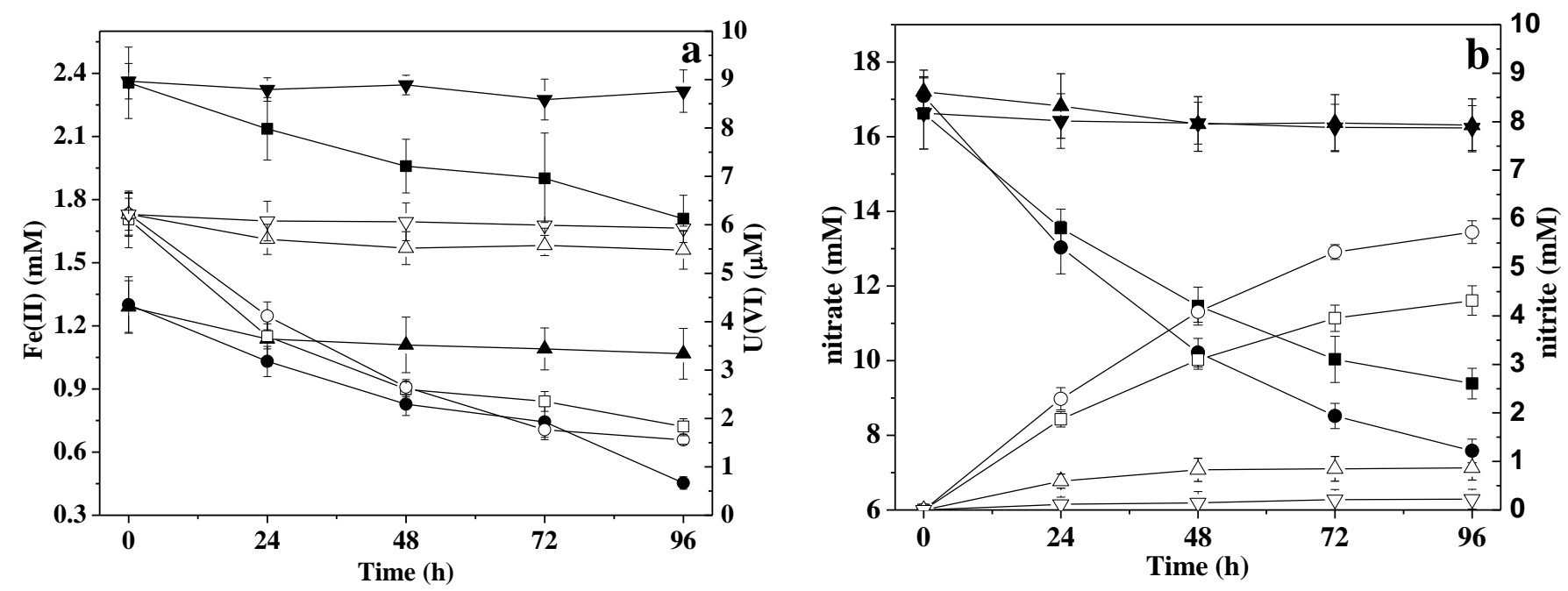

Figure 2. The effects of $\mathrm{pH}$ on changes in $\mathrm{Fe}(\mathrm{II}), \mathrm{U}(\mathrm{VI})$, nitrate, and nitrite concentrations during the growth of Clostridium sp. PXL2. $\square$ and $\square, \mathrm{pH} 5.5 ; \boldsymbol{\nabla}$ and $\nabla, \mathrm{pH} 5.5$ (non-inoculated control (1)); • and $\bigcirc, \mathrm{pH} 7.0 ; \boldsymbol{\Delta}$ and $\triangle$, pH 7.0 (uninoculated control (2). Filled symbols, Fe(II) and nitrate; open symbols, U(VI) and nitrite. (a), Fe(II) and U(VI); (b), nitrate and nitrite. Data shown are means $\pm \mathrm{SD}(n=3)$. 


\subsection{Influence of Oxidation}

Figure 3 shows the changes in $\mathrm{Fe}(\mathrm{II}), \mathrm{U}(\mathrm{VI})$, nitrate, and nitrite concentrations in the groundwater samples over a $2 \mathrm{~h}$ oxidation period after $96 \mathrm{~h}$ of incubation. The $\mathrm{Fe}(\mathrm{II})$ concentrations in the inoculated $\mathrm{pH} 5.5$ and $\mathrm{pH} 7.0$ samples dropped rapidly by $33.6 \%$ and $9.2 \%$ compared to the $37.3 \%$ and $58.9 \%$ losses in the pH 5.5 and pH 7.0 control samples over $2 \mathrm{~h}$ of oxidation (Figure 3). This means that $\mathrm{Fe}(\mathrm{II})$ is much more vulnerable to oxidation by oxygen than to bacterial oxidation. The U(VI) concentrations simultaneously decreased by $30.0 \%$ and $9.8 \%$ in the $\mathrm{pH} 5.5$ and $\mathrm{pH} 7.0$ inoculated samples, while $42.3 \%$ and $60.9 \%$ were lost in the $\mathrm{pH} 5.5$ and $\mathrm{pH} 7.0$ control samples (Figure 3). This rapid and efficient immobilization of $\mathrm{U}(\mathrm{VI})$ in oxic conditions can be explained by the fact that abiotically produced $\mathrm{Fe}(\mathrm{III})$ oxides have a better binding capacity for $\mathrm{U}(\mathrm{VI})$ than biogenic Fe(III) oxides [47]. During the $2 \mathrm{~h}$ oxidation period, the nitrate concentrations in both the inoculated $\mathrm{pH}$ samples decreased slightly $(p>0.05)$ while the nitrite concentrations slightly increased $(p>0.05)$ (Figure 3),implying, therefore, that the facultative bacterium Clostridium sp. PXL2 was still active in oxic conditions.

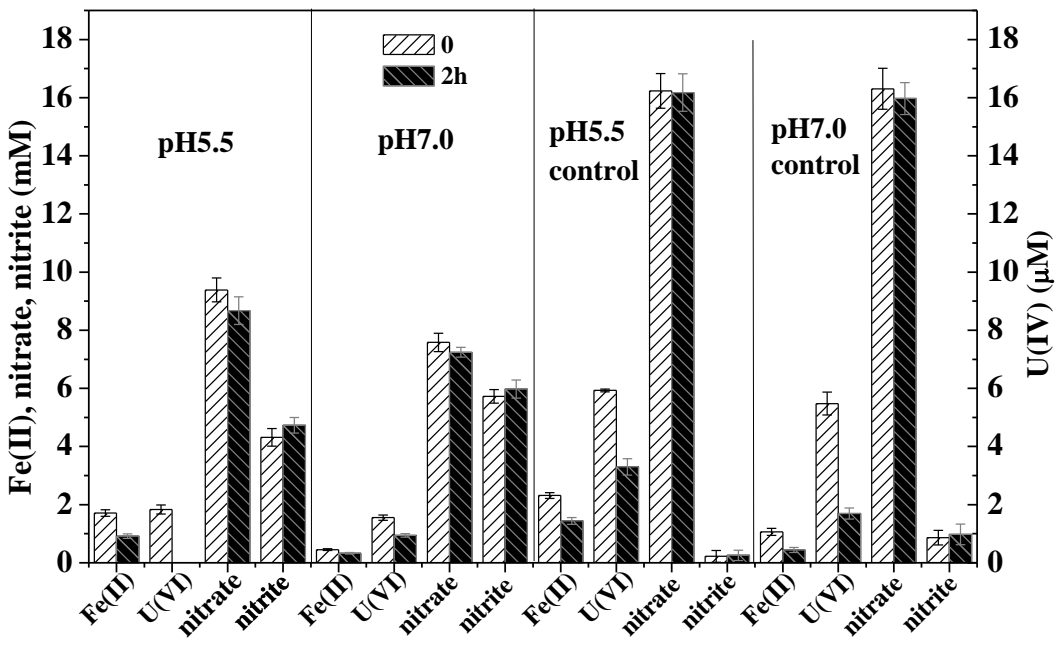

Figure 3. Changes in concentrations of Fe(II), U(VI), nitrate, and nitrite after oxidation for $2 \mathrm{~h}$ following $96 \mathrm{~h}$ of anaerobic incubation. Data shown are means $\pm \operatorname{SD}(n=3)$.

\subsection{Effect of $\mathrm{Fe}(\mathrm{II})$}

Figure 4 shows the effects of $\mathrm{Fe}(\mathrm{II})$ on the changes in the $\mathrm{Fe}(\mathrm{II}), \mathrm{U}(\mathrm{VI})$, nitrate, and nitrite concentrations in the groundwater samples over $96 \mathrm{~h}$ of anoxic incubation. The initial $\mathrm{Fe}$ (II) concentrations of $1.2 \mathrm{mM}$ and $4.0 \mathrm{mM}$ in the groundwater samples decreased rapidly over the first $48 \mathrm{~h}$ before declining slowly to $0.4 \mathrm{mM}$ and $2.5 \mathrm{mM}$ after $96 \mathrm{~h}$, with $66.7 \%$ and $37.5 \%$ levels of oxidation, respectively (Figure 4a). This low Fe(II) conversion to $\mathrm{Fe}(\mathrm{III})$ at a high initial Fe(II) concentration was due to the fact that the bacterial cells tended to settle at the bottom of the reaction vessel with the produced Fe(III) oxides, inhibiting the further oxidation of $\mathrm{Fe}$ (II) in the system. Furthermore, it is possible that $\mathrm{Fe}(\mathrm{III})$ oxides might have toxic effects on bacterial growth [48]. About $73.7 \%$ and $84.5 \%$ of the supplied U(VI) were immobilized from the initial concentrations of $6.34 \mu \mathrm{M}$ and $6.39 \mu \mathrm{M}$, respectively (Figure 4a). The molar ratios of $\mathrm{U}(\mathrm{VI})$ immobilization to $\mathrm{Fe}(\mathrm{II})$ oxidation were 0.0058 and 0.0036, indicating that the $\mathrm{U}(\mathrm{VI})$ immobilization was more efficient at lower Fe(II) concentrations. It is also noticeable from Figure 4 a that the $\mathrm{U}(\mathrm{VI})$ concentration in the control sample without the Fe(II) addition was reduced slightly $(p>0.05)$, probably due to biosorption to the bacterial cells. Bacterial cell walls contain ligands such as phosphate, carboxyl, hydroxyl, sulfhydryl, and amine groups, which are able to bind metal cations [9]. As can be seen from Figure $4 b$, the concentration of nitrate within the samples showed a rapid decrease during the initial $48 \mathrm{~h}$ but gradually subsided to under $44.3-58.1 \%$ reduction in the $96 \mathrm{~h}$ from an initial concentration of about $17 \mathrm{mM}$. It is also noticeable that the nitrate 
reduction (58.1\%) was higher in the control sample than in the $1.2 \mathrm{mM} \mathrm{Fe}(\mathrm{II})(54.2 \%)$ and $4.0 \mathrm{mM}$ Fe(II) (44.3\%) samples. The higher nitrate reduction in the $1.2 \mathrm{mM} \mathrm{Fe}(\mathrm{II})$ sample than in the $4.0 \mathrm{mM} \mathrm{Fe}(\mathrm{II})$ sample further suggests that high Fe(II) levels inhibited the bacterial growth.
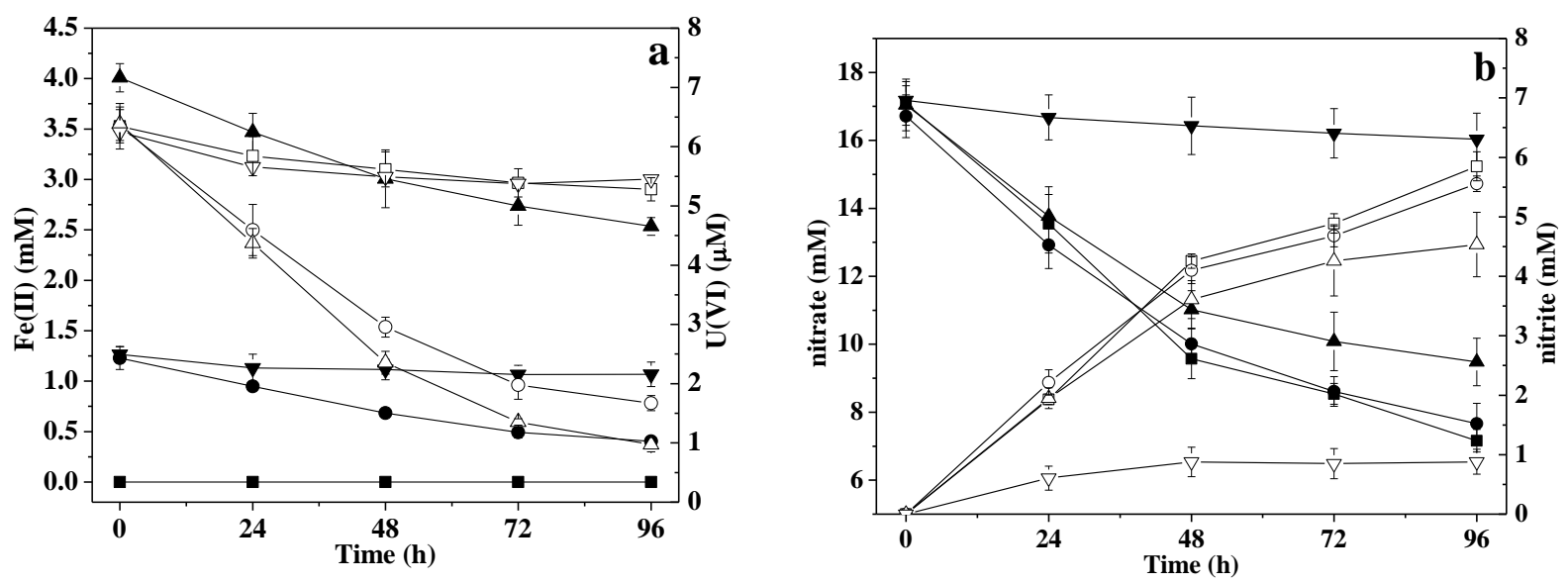

Figure 4. The effects of $\mathrm{Fe}(\mathrm{II})$ on changes in $\mathrm{Fe}(\mathrm{II}), \mathrm{U}(\mathrm{VI})$, nitrate, and nitrite concentrations during the growth of Clostridium sp. PXL2. $\square$ and $\square, 0 \mathrm{mM} \mathrm{Fe(II)} \mathrm{(control);} \mathrm{\bullet} \mathrm{and} \bigcirc, 1.2 \mathrm{mM} \mathrm{Fe}(\mathrm{II}) ; \boldsymbol{\Delta}$ and $\triangle, 4.0 \mathrm{mM} \mathrm{Fe}(\mathrm{II}) ; \boldsymbol{\nabla}$ and $\nabla, 1.2 \mathrm{mM} F e(\mathrm{II})$ (uninoculated). Filled symbols, Fe(II) and nitrate; open symbols, U(VI) and nitrite. (a), Fe(II) and U(VI); (b), nitrate and nitrite. Data shown are means $\pm \mathrm{SD}(n=3)$.

\subsection{SEM-EDS Analysis}

Figure 5 shows Clostridium sp. PXL2 and sediments containing various concentrations of Fe(II), U(VI), and other elements. The Clostridium sp. PLX2 cells were approximately $1.8 \mu \mathrm{m}$ in length. Amorphous iron oxides were observed on the cell surfaces and crystalline iron oxides were not observed. The formation of amorphous iron oxides by some other AFODN species has also been reported $[49,50]$. Figure 6 shows the elemental composition of the sediments around the bacteria cells. The following, including $\mathrm{C}, \mathrm{O}, \mathrm{N}, \mathrm{Fe}$, and a small of proportion of $\mathrm{P}, \mathrm{U}$, and $\mathrm{S}$ based on their weight, primarily formed the sediments' composition. The $\mathrm{U}(\mathrm{VI})$ percentages were $0.17 \%$ and $0.14 \%$ for $\mathrm{D} 1$ and $\mathrm{D} 2$ spots, indicating that the $\mathrm{U}(\mathrm{VI})$ was mainly immobilized due to adsorption on iron oxides produced by Clostridium sp. PXL2. The slightly higher content of U(VI) in D1 could be attributed to biosorption by bacterial cells [9].

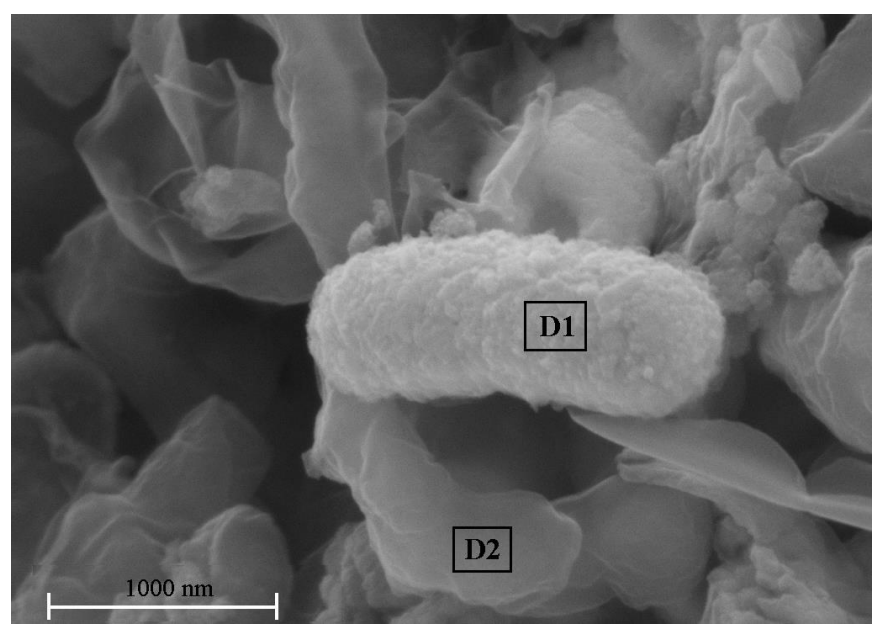

Figure 5. SEM image of sediment from the Clostridium sp. PXL2 cultures. D1 and D2 are typical spot locations for EDS analysis on and around the bacterial cells. Typical images are shown from one of triplicate examinations. 


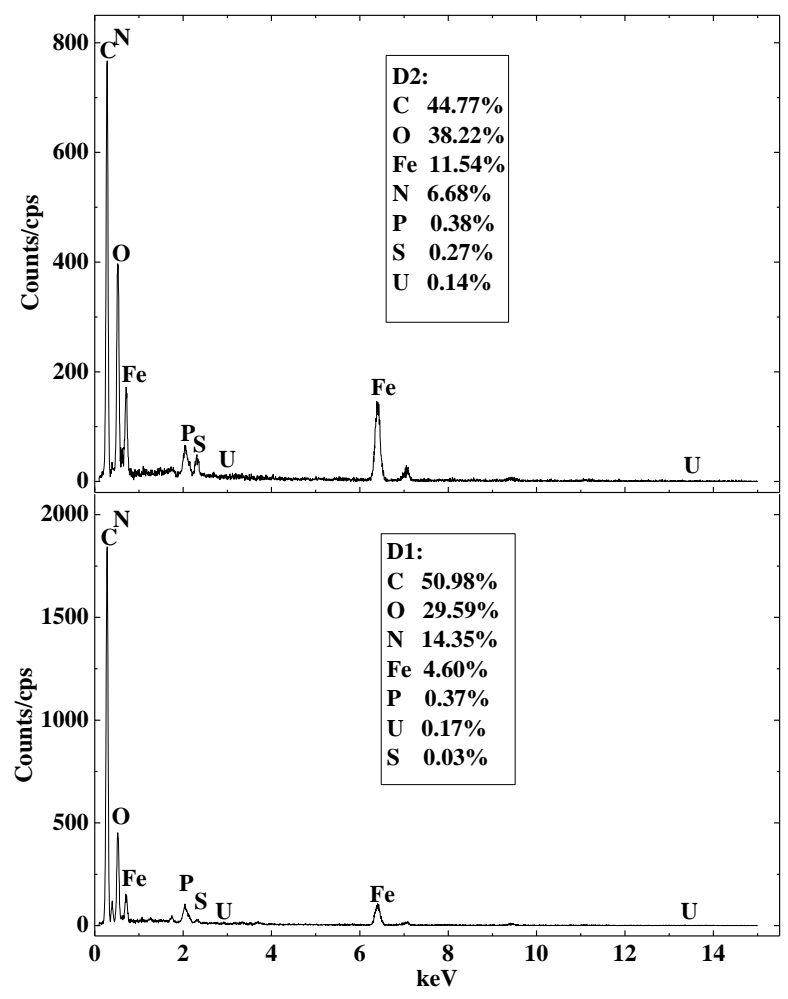

Figure 6. EDS analysis of the Clostridium sp. PXL2 sediment (corresponding to spots D1 and D2 in Figure 5). Typical spectra are shown from one of triplicate determinations.

\section{Conclusions}

Our results demonstrated that the AFODN bacterium Clostridium sp. PXL2 could simultaneously remove $\mathrm{U}(\mathrm{VI})$ and nitrate from polluted groundwater. The removal efficiency of these two pollutants was affected by environmental factors such as $\mathrm{pH}$, redox conditions, and initial Fe(II) concentration. SEM-EDS analysis showed that the U(VI) was immobilized mainly by sorption to poorly crystalline ferric oxides that were produced by Clostridium sp. PXL2. Therefore, nitrate-dependent Fe(II) oxidizing bacteria including Clostridium sp. PXL2 are effective microbes for the bioremediation of uranium- and nitrate-contaminated groundwater after the in situ leach mining of uranium.

Author Contributions: X.P., W.L. and R.W. conceived the ideas and designed this study; R.W., J.D. and J.F. interpreted the data of spatial distribution and structure characteristics and analysis; R.W. wrote the manuscript; X.P. reviewed the manuscript. All authors have read and agreed to the published version of the manuscript.

Funding: This research was supported by Science and Technology Department of Xinjiang Uyghur Autonomous Region (2017B03014-1, 2, 3, 2018D04013), the West Light Foundation of Chinese Academy of Sciences (2018-XBQNXZ-B-014, 2017-XBQNXZ-B-011).

Institutional Review Board Statement: This study does not involve humans and animals.

Informed Consent Statement: This study does not involve any humans.

Data Availability Statement: This study did not report any dada.

Acknowledgments: The authors are grateful to the experimenters at the center Laboratory of Xinjiang Institute of Ecology and Geography for their assistance during the experiment. We also thank Friday U. Ochege for editing the English text of a draft of this manuscript.

Conflicts of Interest: The authors declare that they have no known competing financial interest or personal relationships that could have appeared to influence the work reported in this paper. 


\section{References}

1. OECD-NEA; IAEA. Environmental Activities in Uranium Mining and Milling; OECD Publishing: Paris, France, $1999 ;$ p. 173.

2. Wu, W.; Carley, J.; Fienen, M.; Mehlhorn, T.; Lowe, K.; Nyman, J.; Luo, J.; Gentile, M.; Rajan, R.; Wagner, D. Pilot-scale in situ bioremediation of uranium in a highly contaminated aquifer. 1. Conditioning of a treatment zone. Environ. Sci. Technol. 2006, 40, 3978-3985. [CrossRef] [PubMed]

3. Wufuer, R.; Song, W.; Zhang, D.; Pan, X.; Gadd, G.M. A survey of uranium levels in urine and hair of people living in a coal mining area in Yili, Xinjiang, China. J. Environ. Radioact. 2018, 189, 168-174. [CrossRef] [PubMed]

4. ATSDR. Toxicological Profile for Uranium; Agency for Toxic Substances and Disease Registry: Atlanta, GA, USA, $1999 ;$ p. 462.

5. Choy, C.C.; Korfiatis, G.P.; Meng, X. Removal of depleted uranium from contaminated soils. J. Hazard. Mater. 2006, 136, 53-60. [CrossRef] [PubMed]

6. WHO. Guidelines for Drinking Water Quality; The World Health Organisation: Geneva, Switzerland, 1998.

7. USEPA. Drinking Water Contaminants; 1999. Available online: http://www.epa.gov/safewater/contaminants/index.html (accessed on 25 December 2015).

8. Istok, J.D.; Senko, J.M.; Krumholz, L.R.; Watson, D.; Bogle, M.A.; Peacock, A.; Chang, Y.-J.; White, D.C. In Situ Bioreduction of Technetium and Uranium iii a Nitrate-Contaminated Aquifer. Environ. Sci. Technol. 2004, 38, 468-475. [CrossRef]

9. Lloyd, J.R.; Macaskie, L.E. Bioremediation of radionuclide-containing wastewaters. In Environmental Microbe-Metal Interactions; ASM Press: Washington, DC, USA, 2000; pp. 277-327.

10. Abdelouas, A.; Lutze, W.; Gong, W.; Nuttall, E.H.; Travis, B.J. Biological reduction of uranium in groundwater and subsurface soil. Sci. Total Environ. 2000, 250, 21-35. [CrossRef]

11. Fan, A.M.; Steinberg, V.E. Health Implications of Nitrate and Nitrite in Drinking Water: An Update on Methemoglobinemia Occurrence and Reproductive and Developmental Toxicity. Regul. Toxicol. Pharmacol. Rtp 1996, 23, 35. [CrossRef]

12. Li, B.; Pan, X.; Zhang, D.; Lee, D.J.; Al-Misned, F.A.; Mortuza, M.G. Anaerobic nitrate reduction with oxidation of Fe(II) by Citrobacter Freundii strain PXL1-a potential candidate for simultaneous removal of As and nitrate from groundwater. Ecol. Eng. 2015, 77, 196-201. [CrossRef]

13. Mudd, G.M. Critical review of acid in situ leach uranium mining: 1. USA and Australia. Environ. Geol. 2001, 41, 390-403. [CrossRef]

14. Mudd, G.M. Critical review of acid in situ leach uranium mining: 2. Soviet Block and Asia. Environ. Geol. 2001, 41, 404-416. [CrossRef]

15. Beazley, M.J.; Martinez, R.J.; Webb, S.M.; Sobecky, P.A.; Taillefert, M. The effect of pH and natural microbial phosphatase activity on the speciation of uranium in subsurface soils. Geochim. Cosmochim. Acta 2011, 75, 5648-5663. [CrossRef]

16. Macaskie, L.E.; Bonthrone, K.M.; Yong, P.; Goddard, D.T. Enzymically mediated bioprecipitation of uranium by a Citrobacter sp.: A concerted role for exocellular lipopolysaccharide and associated phosphatase in biomineral formation. Microbiology 2000, 146, 1855-1867. [CrossRef]

17. Kuippers, G.; Morris, K.; Townsend, L.T.; Bots, P.; Lloyd, J.R. Biomineralization of Uranium-Phosphates Fueled by Microbial Degradation of Isosaccharinic Acid (ISA). Environ. Sci. Technol. 2021, 55, 4597-4606. [CrossRef]

18. Lovley, D.R.; Phillips, E.J.; Gorby, Y.A.; Landa ER Lovley, D.R.; Phillips, E.J.; Gorby, Y.A.; Landa, E.R. Microbial reduction of uranium. Nature 1991, 350, 413. [CrossRef]

19. Williams, K.H.; Long, P.E.; Davis, J.A.; Wilkins, M.J.; N'Guessan, A.L.; Steefel, C.I.; Yang, L.; Newcomer, D.; Spane, F.A.; Kerkhof, L.J. Acetate availability and its influence on sustainable bioremediation of uranium-contaminated groundwater. Geomicrobiol. J. 2011, 28, 519-539. [CrossRef]

20. Wang, G.; Yang, S.; Zhou, Y.; Yuan, H.; Shiyou, L.I.; Yijin, L.; Xie, S. Research Progress on the Bioremediation of Groundwater Polluted by Uranium via Bio-reduction. Environ. Sci. Technol. 2019, 42, 47-53.

21. You, W.; Peng, W.; Tian, Z.; Zheng, M. Uranium bioremediation with U(VI)-reducing bacteria. Sci. Total Environ. 2021, 798, 1-15. [CrossRef]

22. Gadd, G.M. Biosorption: Critical review of scientific rationale, environmental importance and significance for pollution treatment. J. Chem. Technol. Biotechnol. 2010, 84, 13-28. [CrossRef]

23. Schiewer, S.; Volesky, B. Biosorption processes for heavy metal removal. Environ. Microbe-Met. Interact. 2000, 14, $329-362$.

24. Suzuki, Y.; Banfield, J.F. Geomicrobiology of uranium. Rev. Minera. Geochem. 1999, 38, 393-432.

25. Coelho, E.; Reis, T.A.; Cotrim, M.; Rizzutto, M.; Corrêa, B. Bioremediation of water contaminated with uranium using Penicillium piscarium. Biotechnol. Prog. 2020, 36, e30322. [CrossRef]

26. Choudhary, S.; Sar, P. Uranium biomineralization by a metal resistant Pseudomonas aeruginosa strain isolated from contaminated mine waste. J. Hazard. Mater. 2011, 186, 336-343. [CrossRef]

27. Anderson, R.T.; Vrionis, H.A.; Ortiz-Bernad, I.; Resch, C.T.; Long, P.E.; Dayvault, R.; Karp, K.; Marutzky, S.; Metzler, D.R.; Peacock, A. Stimulating the in situ activity of geobacter species to remove uranium from the groundwater of a uraniumcontaminated aquifer. Appl. Environ. Microbiol. 2003, 69, 5884-5891. [CrossRef]

28. Duff, M.C.; Hunter, D.B.; Bertsch, P.M.; Amrhein, C. Factors influencing uranium reduction and solubility in evaporation pond sediments. Biogeochemistry 1999, 45, 95-114. [CrossRef] 
29. Wu, W.M.; Carley, J.; Gentry, T.; Ginder-Vogel, M.A.; Criddle, C.S. Pilot-scale in situ bioremedation of uranium in a highly contaminated aquifer. 2. Reduction of $\mathrm{u}(\mathrm{VI})$ and geochemical control of $\mathrm{u}(\mathrm{VI})$ bioavailability. Environ. Sci. Technol. 2006, 40, 3986-3995. [CrossRef] [PubMed]

30. Moon, H.S.; Komlos, J.; Jaffe, P.R. Uranium reoxidation in previously bioreduced sediment by dissolved oxygen and nitrate. Environ. Sci. Technol. 2007, 41, 4587-4592. [CrossRef] [PubMed]

31. Senko, J.M.; Mohamed, Y.; Dewers, T.A.; Krumholz, L.R. Role for Fe(III) minerals in nitrate-dependent microbial U(IV) oxidation. Environ. Sci. Technol. 2005, 39, 2529-2536. [CrossRef] [PubMed]

32. Senko, J.M.; Istok, J.D.; Suflita, J.M.; Krumholz, L.R. In-situ evidence for uranium immobilization and remobilization. Environ. Sci. Technol. 2002, 36, 1491-1496. [CrossRef] [PubMed]

33. Benzerara, K.; Miot, J.; Morin, G.; Ona-Nguema, G.; Skouri-Panet, F.; Ferard, C. Significance, mechanisms and environmental implications of microbial biomineralization. Comptes Rendus-Géoscience 2011, 343, 160-167. [CrossRef]

34. Straub, K.L.; Schonhuber, W.A.; Buchholz-Cleven, B.; Schink, B. Diversity of ferrous iron-oxidizing, nitrate-reducing bacteria and their involvement in oxygen-independent iron cycling. Geomicrobiol. J. 2004, 21, 371-378. [CrossRef]

35. Weber, K.A.; Urrutia, M.M.; Churchill, P.F.; Kukkadapu, R.K.; Roden, E.E. Anaerobic redox cycling of iron by freshwater sediment microorganisms. Environ. Microbiol. 2010, 8, 100-113. [CrossRef]

36. Means, J.L.; Crerar, D.A.; Borcsik, M.P.; Duguid, J.O. Radionuclide adsorption by manganese oxides and implications for radioactive waste disposal. Nature 1978, 274, 44-47. [CrossRef]

37. Means, J.L.; Crerar, D.A.; Borcsik, M.P.; Duguid, J.O. Adsorption of Co and selected actinides by Mn and Fe oxides in soils and sediments. Geochim. Cosmochim. Acta 1978, 42, 1763-1773. [CrossRef]

38. Slanina, J.; Lingerak, W.A.; Bergman, L. A fast determination of nitrate in rain and surface waters by means of UV spectrophotometry. Fresenius Z. Für Anal. Chem. 1976, 280, 365-368. [CrossRef]

39. Gendel, Y.; Lahav, O. Accurate determination of Fe(II) concentrations in the presence of a very high soluble Fe(III) background. Appl. Geochem. 2008, 23, 2123-2129. [CrossRef]

40. Klueglein, N.; Kappler, A. Abiotic oxidation of Fe(II) by reactive nitrogen species in cultures of the nitrate-reducing Fe(II) oxidizer Acidovorax sp. BoFeN1-questioning the existence of enzymatic Fe(II) oxidation. Geobiology 2013, 11, 180-190. [CrossRef]

41. Jauberty, L.; Drogat, N.; Decossas, J.L.; Delpech, V.; Gloaguen, V.; Sol, V. Optimization of the arsenazo-III method for the determination of uranium in water and plant samples. Talanta 2013, 115, 751-754. [CrossRef]

42. Geng, Y.J.; Qi, W.; Muszynski, M.; Hansson, G.K.; Libby, P. Apoptosis of vascular smooth muscle cells induced by in vitro stimulation with interferon- $\gamma$, tumor necrosis factor- $\alpha$, and interleukin-1 $\beta$. Arterioscler. Thromb. 2015, 7, 19-27. [CrossRef]

43. Han, R.; Zou, W.; Wang, Y.; Lu, Z. Removal of uranium(VI) from aqueous solutions by manganese oxide coated zeolite: Discussion of adsorption isotherms and pH effect. J. Environ. Radioact. 2007, 93, 127-143. [CrossRef]

44. Waite, T.D.; Davis, J.A.; Payne, T.E.; Waychunas, G.A.; Xu, N. Uranium(VI) adsorption to ferrihydrite: Application of a surface complexation model. Geochim. Et Cosmochim. Acta 1994, 58, 5465-5478. [CrossRef]

45. Langmuir, D. Aqueous Environmental Geochemistry; Prentice Hall: Hoboken, NJ, USA, 1997.

46. Ulrich, K.U.; Ilton, E.S.; Veeramani, H.; Sharp, J.O.; Bernier-Latmani, R.; Schofield, E.J.; Bargar, J.R.; Giammar, D.E. Comparative dissolution kinetics of biogenic and chemogenic uraninite under oxidizing conditions in the presence of carbonate. Geochim. Cosmochim. Acta 2009, 73, 6065-6083. [CrossRef]

47. Lack, J.G.; Chaudhuri, S.K.; Kelly, S.D.; Kemner, K.M.; O'Connor, S.M.; Coates, J.D. Immobilization of Radionuclides and Heavy Metals through Anaerobic Bio-Oxidation of Fe(II). Appl. Environ. Microbiol. 2002, 68, 2704-2710. [CrossRef]

48. Benckiser, G.; Santiago, S.; Neue, H.U.; Watanabe, I.; Ottow, J.C.G. Effect of fertilization on exudation, dehydrogenase activity, iron-reducing populations and $\mathrm{Fe}^{++}$formation in the rhizosphere of rice (Oryza sativa L.) in relation to iron toxicity. Plant Soil 1984, 79, 305-316. [CrossRef]

49. Kappler, A. Geomicrobiological Cycling of Iron. Rev. Mineral. Geochem. 2005, 59, 85-108. [CrossRef]

50. Li, B.; Tian, C.; Zhang, D.; Pan, X. Anaerobic Nitrate-Dependent Iron (II) Oxidation by a Novel Autotrophic Bacterium, Citrobacter freundii Strain PXL1. Geomicrobiology 2014, 31, 138-144. [CrossRef] 